\title{
Anthropocene environmental change in an internationally important oligotrophic catchment on the Atlantic seaboard of western Europe
}

\author{
C. Dalton ${ }^{a, *}$, B. O'Dwyer ${ }^{b}$, D. Taylor ${ }^{c}$, E. de Eyto ${ }^{d}$, E. Jennings ${ }^{\text {e }}$, G. Chen ${ }^{f}$, \\ R. Poole ${ }^{\mathrm{d}}$, M. Dillane ${ }^{\mathrm{d}}$, P. McGinnity ${ }^{\mathrm{b}}$ \\ ${ }^{a}$ Mary Immaculate College, University of Limerick, Ireland \\ ${ }^{\mathrm{b}}$ School of Biological, Earth \& Environmental Science, University College Cork, Ireland \\ ${ }^{\mathrm{c}}$ National University of Singapore, Singapore \\ ${ }^{\mathrm{d}}$ Marine Institute, Ireland \\ e Dundalk Institute of Technology, Ireland \\ ${ }^{\mathrm{f}}$ Yunan Normal University, China
}

\section{A R T I C L E I N F O}

\section{Article history:}

Received 19 November 2013

Received in revised form 22 May 2014

Accepted 12 June 2014

Available online 5 July 2014

\section{Keywords:}

Aquatic ecosystem

Oligotrophic systems

Climate change

NAO

Palaeoecology

Legacy sediment

\begin{abstract}
A B S T R A C T
Oligotrophic catchments with short spatey streams, upland lakes and peaty soils characterise northwest European Atlantic coastal regions. These catchments are important biodiversity refuges, particularly for sensitive diadromous fish populations but are subject to changes in land use and land management practices associated with afforestation, agriculture and rural development. Quantification of the degree of catchment degradation resulting from such anthropogenic impacts is often limited by a lack of longterm baseline data in what are generally relatively isolated, poorly studied catchments. This research uses a combination of palaeolimnological (radiometrically-dated variations in sedimentary geochemical elements, pollen, diatoms and remains of cladocera), census, and instrumental data, along with hindcast estimates to quantify environmental changes and their aquatic impacts since the late 19 th century. The most likely drivers of any change are also identified. Results confirm an aquatic biotic response (phytoand zooplankton) to soil erosion and nutrient enrichment associated with the onset of commercial conifer afforestation, effects that were subsequently enhanced as a result of increased overgrazing in the catchment and, possibly, climate warming. The implications for the health of aquatic resources in the catchment are discussed.
\end{abstract}

(c) 2014 Elsevier Ltd. All rights reserved.

\section{Introduction}

Oligotrophic headwater drainage systems are of fundamental importance in terms of global freshwater resources. In the north east Atlantic region, these systems often constitute the majority of pristine reference lakes and rivers (Bennion et al., 2004; Leira et al., 2006; Kelly et al., 2009), and support internationally important salmonid populations. Atlantic salmon are an Annex II species under the 1992 European Habitats Directive, and member states are required to conserve its habitat and protect the stock status (O'Keeffe and Dromey, 2004). The sensitivity of oligotrophic waters and their catchments to climate change and the potential reduction in freshwater biodiversity necessitate ongoing scientific focus (Ormerod et al., 2010; Strayer and Dudgeon, 2010). Their

\footnotetext{
* Corresponding author.

E-mail address: catherine.dalton@mic.ul.ie (C. Dalton).
}

remote location has enabled some relative protection from more obvious anthropogenic disturbances, such as intensive agriculture and industry. However, the isolation of headwater catchments often results in their being relatively poorly studied and data poor, deficiencies that can compromise understanding of the risk posed by environmental change and effective management responses.

In western Ireland, headwaters are generally found in acid sensitive catchments in which hydrology and flood regimes are dependent on climate while surface waters are oligotrophic with relatively low primary productivity. Catchment degradation, attributed to land use and land management policies associated with afforestation, agriculture and rural development (Moriarty and Dekker, 1997; Hendry et al., 2003; Crozier et al., 2003) have impacted freshwater quality, quantity and habitat. Since the 1950s, agriculturally unproductive, generally poorly-drained, upland catchments across Ireland were targeted for commercial coniferous afforestation (Black et al., 2008) generally planted without riparian buffer strip protection. Thus the commercial benefits of 
afforestation have been associated with environmental costs, ranging from acidification (Allott et al., 1990, 1997; Kelly-Quinn et al., 1996, 1997; Cruikshanks et al., 2008; Feeley et al., 2011), sediment release (Rodgers et al., 2010), nutrient enrichment (Rodgers et al., 2010; Drinan et al., 2013a) to hydrological changes (Drinan et al., 2013b). For example, many studies have highlighted the exacerbating effect of forestry on water draining forested peatlands (Allott et al., 1990, 1997; Dalton, 2000) and episodic acidifying events (Kowalik et al., 2007; Evans et al., 2008; Ormerod and Durance, 2009; O’Dwyer and Taylor, 2010; Feeley et al., 2011). Many headwaters occur in naturally acidic peatland catchments, where forestry practices can increase the loading of allochthonous dissolved organic carbon (DOC) and lead to fundamental changes in trophic status and biological processes in lakes (Cole et al., 2011). For example, reduction in water clarity can restrict autotrophic production while DOC can fuel microbial metabolism (Jasser and Arvola, 2003; Sucker and Krause, 2010). Anthropogenically-exacerbated acidification at these sites can greatly increase aquatic effects, including changes in the quality of primary producers, extirpation of macroinvertebrates and decreased fish spawning efforts and survival rates (Kowalik et al., 2007; Kroglund et al., 2007).

Drainage works associated with afforestation (Carling et al., 2001) have precipitated changes in hydrological regimes and increased erosion risk (Müller, 2000). Nutrient-poor peat soils with thin vegetation cover in upland catchments are susceptible to damage from such erosion (Gordon et al., 2001; Watts et al., 2003), leading to increased sediment loads in downstream receiving waters and changes in ecological quality (e.g. elimination of species or switch in species dominance) (Kowalik and Ormerod, 2006; Drinan et al., 2013a). Excessive erosion has also been associated with overgrazing by sheep (Soulsby et al., 2001a; Allott et al., 2005). Stocking levels of sheep in the west of Ireland increased sharply from the early 1970s as a result of EU subsidies (Gillmor and Walsh, 1993; Weir, 1996; O'Connor, 2000) with degradation of upland areas in particular commonplace. Erosion of peat in headwater catchments results in excess levels of suspended sediment entering receiving waters (Wood and Armitage, 1997; Heaney et al., 2001; Mainstone et al., 2008). This leads to legacy sediment or rates of sediment accumulation in downstream lakes far in excess of those expected in the absence of anthropogenic disturbance (James, 2013). Excess sediment loads can have major ecological impacts on resident fish populations, for example, by reducing visibility in streams and hence affecting predation, or by modifying habitats and suffocating spawning beds and thereby reducing egg survival of salmon and trout (Soulsby et al., 2001b; Suttle et al., 2004). In addition, particulate forms of phosphorus (P), nitrogen $(\mathrm{N})$ and carbon $(\mathrm{C})$ are carried along with eroded material causing enrichment effects in receiving waters. The sources of nutrients under such circumstances may be anthropogenic fertilisation of commercial forestry or agricultural lands ( $P$ and $\mathrm{N}$ ), forest harvest operations, or peat degradation leading to erosion of the terrestrial C pool (Cummins and Farrell, 2003; Rodgers et al., 2010; Drinan et al., 2013b) with aquatic impacts extending downstream.

Climate variability can also influence the nature and magnitude of aquatic effects of catchment disturbance, in addition to being a driver of change in its own right (Jennings et al., 2000; Battarbee et al., 2002). Future climate projections for catchments along the north east Atlantic coast include increases in air and water temperatures, frequency of storm events, and rate of DOC loss (Fealy et al., 2010; Jennings et al., 2010; Naden et al., 2010). Future management of these types of catchments requires sound understanding of how multiple drivers have shaped current ecological conditions and are projected to do so in coming years.

A cause-effect relationship between catchment degradation and declines in water quality is plausible but questions remain about the relative strengths of climate and land use effects. Moreover, little research has focused on understanding the consequences of aquatic risks of climate and land use changes acting in unison. In the absence of long-term datasets, evidence of past drivers of aquatic ecosystem changes and their effects preserved in lake sediments and recovered through palaeolimnological techniques can potentially provide a useful source of proxy evidence (Battarbee et al., 2002; Dalton et al., 2009; Smol, 2010). Sediment-based archives represent datable accumulations of autochthonous and allochthonous material, in the form of biological, chemical and physical components. Research presented in this paper tests the null hypothesis $\left(\mathrm{H}_{0}\right)$ that there is no relationship between changing environmental conditions in an upland peat catchment on the Atlantic seaboard of western Europe and aquatic responses during a period (beginning in the late 19th century) that accommodates a large part of the Anthropocene. The Burrishoole catchment in the west of Ireland, a nationally and internationally important index site for monitoring stocks of diadromous fish (Whelan et al., 1998; ICES, 2012, 2013), is the focus of the study.

\section{Materials and methods}

\section{Study site}

The Burrishoole catchment $\left(53^{\circ} 56^{\prime} \mathrm{N}, 9^{\circ} 35^{\prime} \mathrm{W}\right)$, a sparsely populated area (c. $100 \mathrm{~km}^{2}$ ) of generally extensively grazed upland peat soils and coniferous plantation forestry (Fig. 1), is climatically influenced by the Atlantic Ocean (Allott et al., 2005). Catchment bedrocks are quartzites and schists/gneiss overlain by poorly drained soils. The headwater lake Bunaveela and a downstream lake, Feeagh, are both deep, oligotrophic and coloured (respectively, maximum depths of $23 \mathrm{~m}$ and $45 \mathrm{~m} ; 12$ and $8 \mu \mathrm{g} \mathrm{l}^{-1} \mathrm{TP}$; and 68 and $80 \mathrm{mg} \mathrm{l}^{-1} \mathrm{PtCo}$ ), the latter because of high levels of DOC, and have low alkalinity and pH (see Supplementary Data (SD) Table 1). For the purposes of the EU Water Framework Directive (WFD), Feeagh is currently classified as being of 'Good' ecological status (McGarrigle et al., 2010), and is assigned to the risk category 2a (expected to achieve good ecological status) (Anon., 2005).

\section{Historical and instrumental data}

Climate data (air temperature and precipitation) were available for the Newport meteorological station, located within the catchment (1968 to present) and for Belmullet synoptic station, $40 \mathrm{~km}$ northwest of the catchment (1956 to present). Data were also obtained for the Arctic multidecadal oscillation (AMO), the North Atlantic Oscillation Index (NAO) and the Gulf Stream North Wall Index (GSI). The AMO and NAO are related to large-scale weather events (NAO is thought to be a function of the larger scale AMO) while the GSI is related to a measure of the latitude of the Gulf Stream current. The NAO Index is based on the pressure difference at locations representative of the strength of the Azores high and of the Icelandic low (Hurrell, 1995). Highly positive values are associated with an increase in the occurrence of westerly winds and increased wind speeds, temperatures and rainfall in northern Europe (Jennings et al., 2000). There are several versions of the NAO index: here the winter version (average values for the months of December, January, February, and March: Hurrells Index) for the period 1864-2009 is used. The index provided a proxy for local and regional climate for the full time period, especially the earlier period when meteorological data were unavailable.

Population data from 1970 were available from the Central Statistics Office (CSO) in Ireland for district electoral divisions (DEDs), while pre-1970 data are estimates based on rural district data from paper records. Changes in land use were compiled from 


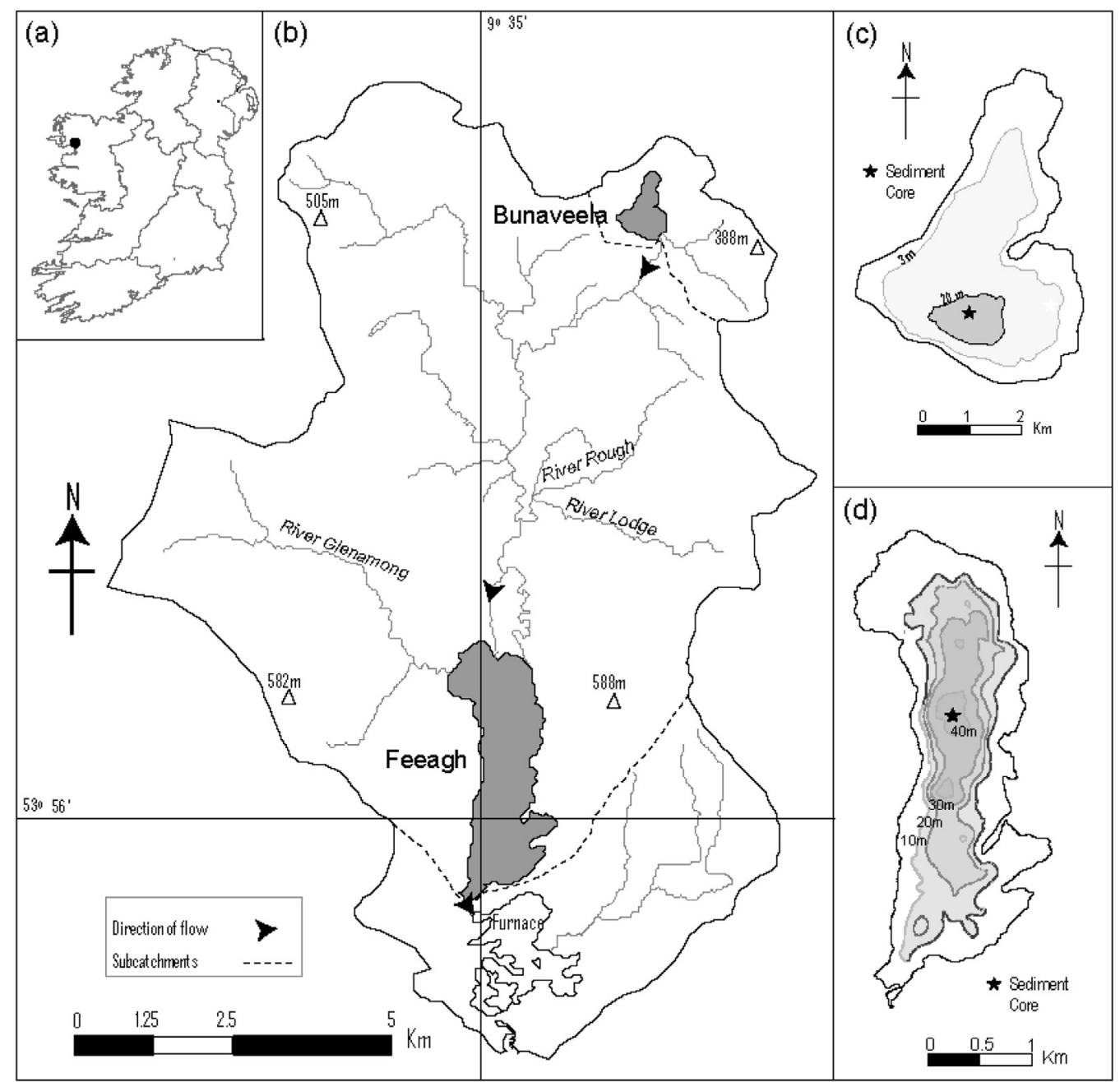

Fig. 1. Study area: (a) Western River Basin District location (b) the Burrishoole catchment, (c) Bunaveela bathymetry and (d) Feeagh bathymentry.

CORINE data, decadal-interval census land use data, and commercial afforestation records. Hindcast total phosphorus (TP) loads for human, livestock and land export were established using an export coefficient approach (Johnes, 1996) to quantify and infer relative historical catchment pressures from nutrient loading.

\section{Sediment core collection and chronology development}

Four sediment cores were collected in 2006 from the deepest parts of lakes Bunaveela and Feeagh using a gravity corer (Renberg and Hansson, 2008). The cores were sub-sampled at $1 \mathrm{~cm}$ intervals (analytical resolution is provided in SD Table 2). Chronological control was based upon measurements of activity of radioactive isotopes $\left({ }^{210} \mathrm{~Pb} /{ }^{210} \mathrm{Po}\right.$ and $\left.{ }^{137} \mathrm{Cs}\right)$ at the laboratories of Flett Research Ltd, Canada. The ${ }^{210}$ Po isotope was measured using Ortec 'Ortet' alpha spectrometry. Dates and sediment accumulation rate (SAR) was calculated on a single core from each lake using the Constant Initial Concentration (CIC) and Constant Rate of Supply (CRS) models, with the latter adopted (Appleby, 2001). CRS-SAR estimates were validated with reference to ${ }^{137} \mathrm{Cs}$ fallout chronostratigraphic markers (1986 Chernobyl and 1963 weapons testing). Sediment accumulation rates and ages were extrapolated to the other adjacent sediment cores from the same deepwater site. Percentage loss-on-ignition (\% LOI) was applied to provide a measure of relative proportions of organic and inorganic matter in the sediment (Heiri et al., 2001) and was used to adjust for relatively minor differences in sedimentation between adjacent cores, and therefore as a basis for extending a chronology established for one core to other, closely-distanced cores.

Proxies

Up-core variations in levels of geochemical elements ( $\mathrm{Al}, \mathrm{Ca}, \mathrm{Fe}$, $\mathrm{K}, \mathrm{Mn}, \mathrm{Na}, \mathrm{P}$ and $\mathrm{N}$ ) were determined using sequential acid digestion, using $\mathrm{HF}$ to break down silicates, $\mathrm{HNO}_{3}$ to oxidise the organic matter, and $\mathrm{H}_{2} \mathrm{O}_{2}$ to oxidise the resistant organics (Bock, 1979); concentrations were established using inductively coupled plasma optical emission spectroscopy (ICP-OES) (Stefánsson et al., 2007). Geochemical accumulation rates were also calculated based on the product of chemical concentration $\left(\mathrm{mg} \mathrm{g}^{-1}\right)$ and SAR $\left(\mathrm{g} \mathrm{cm}^{-2} \mathrm{yr}^{-1}\right.$ ) data while enrichment factor (EF)s were employed to distinguish between natural and anthropogenic sources of geochemical elements (Binford, 1990). The EF method is calculated on element concentrations, with $\mathrm{Al}$ used as a passive tracer element to reflect the natural contribution of geochemical inputs (EF function $=(\mathrm{M} / \mathrm{Al})$ sample $/(\mathrm{M} / \mathrm{Al})$ basal core sample ( where $\mathrm{M}$ is the metal studied)) (Binford, 1990; Norton et al., 1992). Stable C and $\mathrm{N}$ isotopic measurements and $\mathrm{C}: \mathrm{N}$ ratios were used to determine the source(s) of organic matter (Cerling, 1999; Wolfe et al., 2001; Meyers, 2003), based on procedures described in Lohse et al. (2000), Talbot (2001) and Wolfe et al. (2001). Isotope measurements were made using a Thermo Delta ${ }^{\text {plus }}$ Continuous Flow Isotope Ratio Mass Spectrometer (CF-IRMS). 
Diatoms were prepared using the methodology outlined in Battarbee et al. (2001). Taxonomic identification (>300 valves sample $^{-1} ; 2 \mathrm{~cm}$ ) mainly followed Krammer and Lange-Bertalot (1986-1991). Diatom inferred (DI)-TP and DI-pH were calculated using a 70-lake diatom TP model $\left(r_{\text {jack }}^{2}=0.74\right.$; RMSEP $\left.=0.21\right)$ and $\mathrm{pH}$ model $\left(r_{\mathrm{jack}}^{2}=0.89\right.$; RMSEP $\left.=0.32\right)$ for the Irish Ecoregion described in Chen et al. (2008). Cladocera remains (c. 300 individuals sample ${ }^{-1}$ ) were extracted from four samples from Feeagh using a modified version of the standard method described by Frey (1986). As well as counting the often more abundant pelagic specimens, at least $70-100$ benthic (chydorid) individuals were counted to enable calculation of benthic/planktonic ratios. Analysis of pollen (minimum 300 grains sample ${ }^{-1} ; 2-4 \mathrm{~cm}$ sample interval) preserved in lake sediments followed standard protocols (Bennett and Willis, 2001), with identification based upon reference to type material and to Moore et al. (1991).

\section{Statistical analysis}

The extent and optimum number of stratigraphic zones in the geochemical, pollen and diatom data were identified using CONISS (Grimm, 1987) and the 'broken-stick' model (Bennett, 1996). To explore the relationships between sediment proxies and historical and instrumental data, multivariate ordination methods were applied using CANOCO (version 4.5) (ter Braak and Šmilauer, 2002) and illustrated using the computer software package $C 2$ version 4 (Juggins, 2003). Detrended correspondence analyses (DCA) indicated gradients less than 2.5 standard deviation units and consequently linear methods were applied (Birks et al., 2012). Principle components analysis (PCA) was conducted on a reduced diatom dataset (species occurrence $>5 \%$ in more than two samples) to summarise the diatom floristic data. Redundancy Analysis (RDA), with restricted permutations due to temporal autocorrelation, was used to examine variation in lake sediment data in conjunction with possible explanatory environmental variables. An a priori basedchoice of response variables included sediment physical, geochemical and biological responses along with climate, census and modelled explanatory variables. Significance tests of the relationship between the explanatory and response variables were enabled by Monte Carlo Permutation tests in CANOCO. Data interpolations were necessary due to inter-dataset differences in temporal resolution (e.g. annual instrumental data and decadal census data), while the time period accommodated within a $1 \mathrm{~cm}$-thick sediment sample varied according to SAR. Data interpolation and temporal matching of upcore variations in \%LOI using CSPLOT, an unpublished computer programme (Malcolm Clarke pers. Comm.) was applied in order to enable cross-comparison on an annual timestep. All data were $\log (x+c)$ transformed.

\section{Results}

\section{Historical and instrumental data}

Summaries of temporal variations in climate and environmental data, compiled from instrumental and historical records for a range of post-1850 time periods, are illustrated in Fig. 2. A slight but increasingly positive trend in the NAO index used is evident from 1960 to 1995. Larger variations in AMO are apparent with negative values evident in the early 1900s and increasingly positive values evident from the 1920 s and the early 1970s, the latter coincident with increases in GSI. Average annual air temperature at Newport for the period 1960 to 2008 was $10.2^{\circ} \mathrm{C}$ and annual average annual precipitation $1570 \mathrm{~mm}_{\text {year }}{ }^{-1}$. 1. A significant upward trend $\left(r^{2}=0.26 ; p<0.0005\right)$ was evident in temperature, while no overall trend in precipitation was apparent.

Cattle numbers in the catchment have been consistently low since the early $1900 \mathrm{~s}\left(<5 \mathrm{~km}^{-2}\right)$ owing to a shortage of pasture (Fig. 2). By comparison, sheep numbers have increased rapidly from the 1970s, reaching a high by 2000, before decreasing. Human population levels in the catchment have been consistently low. Afforestation has been the most significant change in land use over time. In total, commercial forestry currently accounts for about $23 \%$ of the total catchment area. Afforestation commenced in 1951 and expanded between 1960 and 1969. Hindcast modelled P exports from the Burrishoole catchment, based on the historical census data, were relatively stable until the 1960s, after which they increased sharply following the commencement of afforestation in the catchment, but just prior to an increase in sheep numbers (Fig. 2). The increase in modelled TP continued into the 1990 s as sheep numbers in the catchment increased, before stabilising.

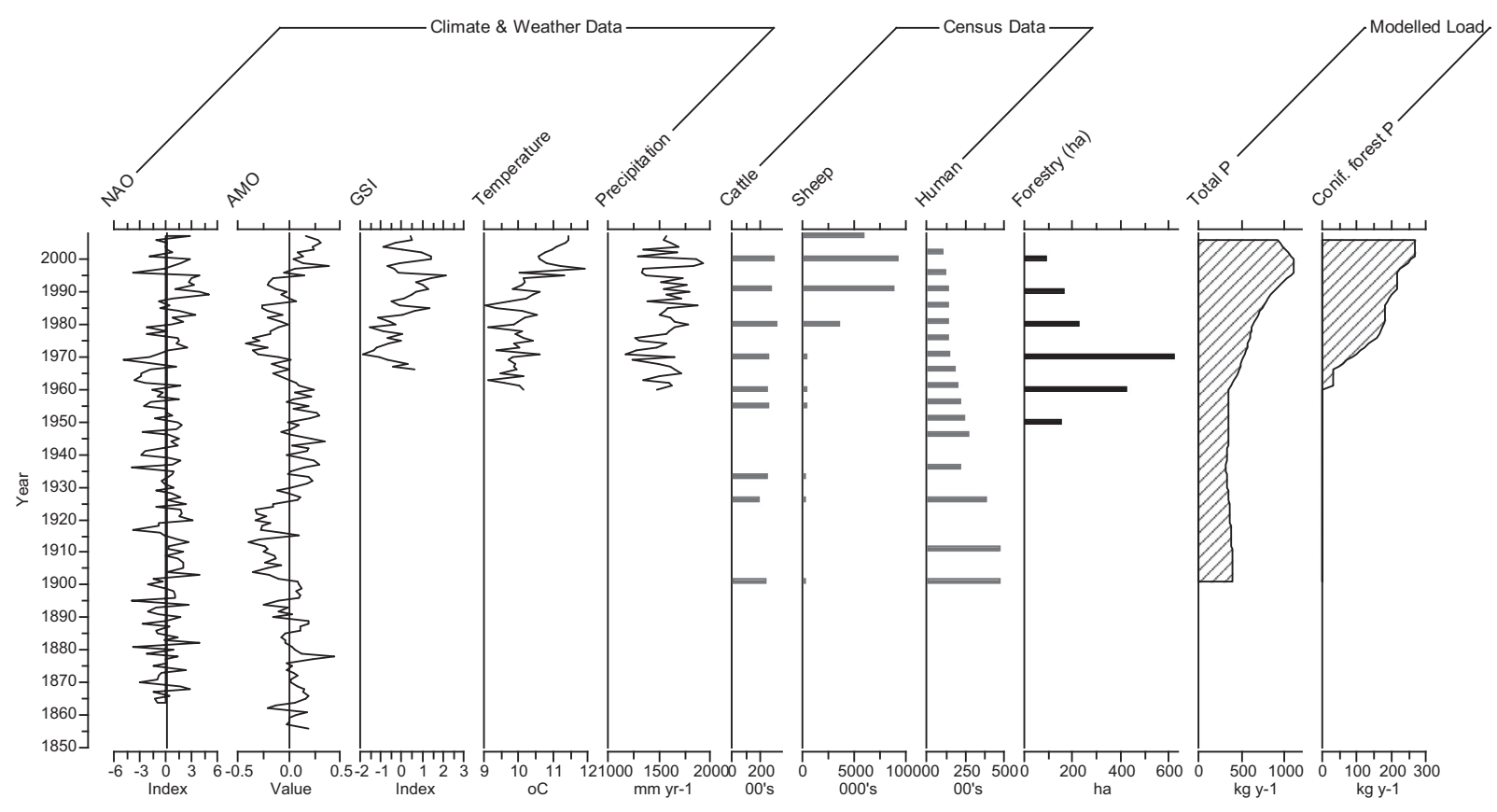

Fig. 2. Burrishoole climate, weather, census records and export coefficient catchment TP load. 

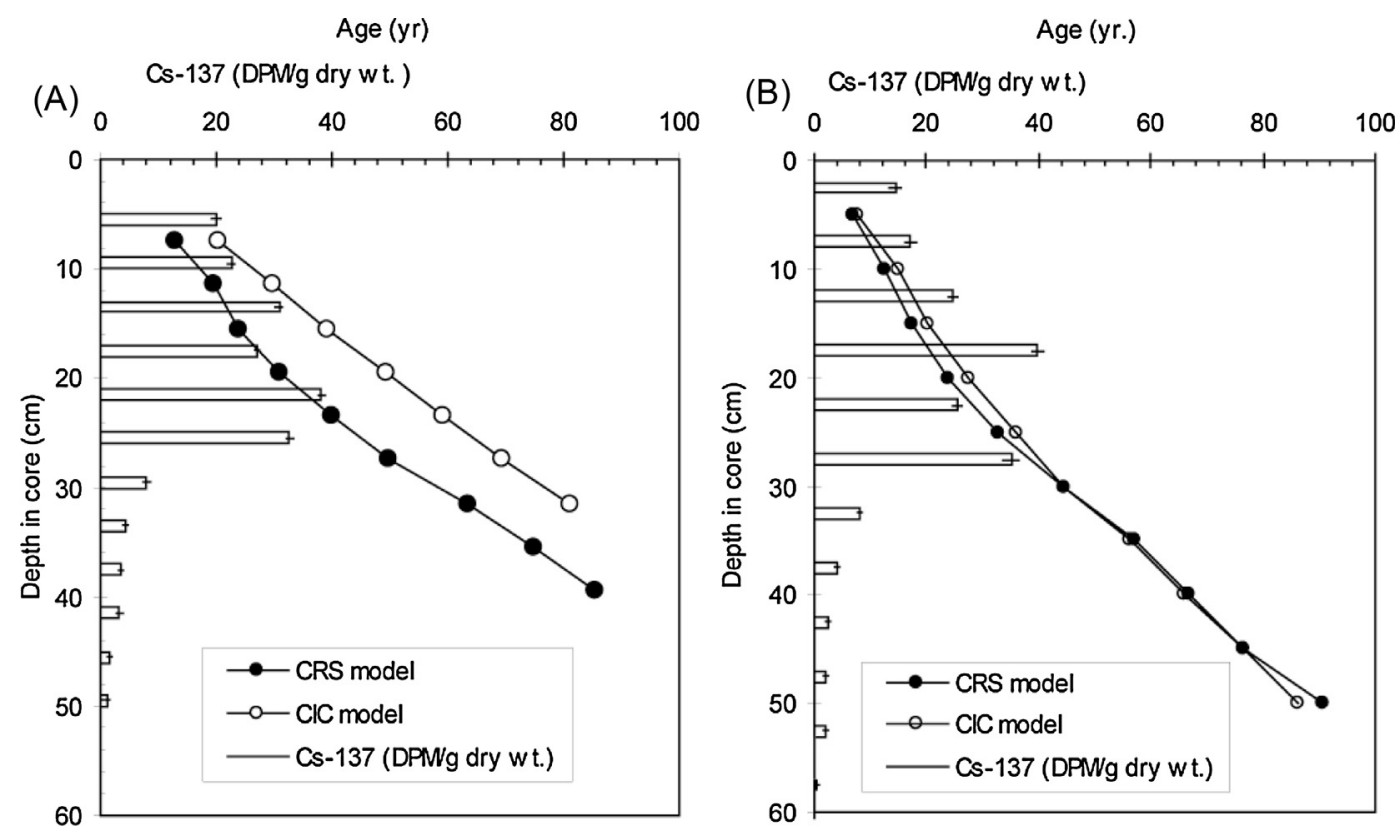

Fig. 3. Age (yr) vs. depth (cm) (CRS and Linear Regression models) and ${ }^{137}$ Cs activity (DPM/g dry wt.) for (a) Bunaveela and (b) Feeagh.

\section{Sediment chronologies}

Levels of excess ${ }^{210}$ Po decrease exponentially with sediment depth in Bunaveela and Feeagh (Fig. 3; SD Table 3). CRS estimated SAR increased up-core in Bunaveela (0.14-0.36 $\left.\mathrm{g} \mathrm{cm}^{-2} \mathrm{yr}^{-1}\right)$ and in Feeagh $\left(0.15-0.29 \mathrm{~g} \mathrm{~cm}^{-2} \mathrm{yr}^{-1}\right)$ with the lowermost samples dating to the early 1890s. Baseline accumulation rates were generally between 0.1 and $0.15 \mathrm{~g} \mathrm{~cm}^{-2}$ while post-1960 SARs were in excess of $0.2 \mathrm{~g} \mathrm{~cm}^{-2}$. These estimated dates receive support from measured activities of ${ }^{137} \mathrm{Cs}$. It must be noted that predicted ages greater than 80 years are approximations only.

\section{Proxies}

Organic matter (\%LOI) fluctuated throughout the sediment cores with increases evident from c. 1985 in Bunaveela ( 28 to 40\%LOI) and c. 1960 in Feeagh ( 27 to 46\%LOI) (Fig. 4). Increases in levels of \%C ( $\sim 10$ to 20$)$ and $\delta^{15} \mathrm{~N}(<2$ to 2.5$)$ in Feeagh coincide with organic matter increases and are within the range characteristic of terrestrial plants (Meyers, 2003). Ratios of C/N $>20$ in both lakes are indicative of a predominantly terrestrial source for organic matter.

Temporal variation in levels of chemical elements for Bunaveela (Fig. 5) and Feeagh (Fig. 6) are expressed in concentration and accumulation rate, and as EFs. Up-core variations in concentration and accumulation rate data for chemical elements were grouped into six zones for Bunaveela. Measured levels of the major, redoxsensitive and nutrient elements remained relatively constant in zone G-B-1 and G-B-2. In contrast, accumulation rates of all elements increase in G-B-3 from c. 1950, reaching a peak at c. 1980 before declining in G-B-4. Zones G-B-5 and G-B-6 were characterised by fluctuating amounts of the major elements and a sharp increase in levels of both the redox-sensitive and nutrient elements. EFs greater than background levels from the late 1980s indicate increased anthropogenic inputs in the relatively recent past for all elements apart from K. Data from Feeagh were grouped into five zones and levels of both the major and redox-sensitive elements peak at c. 1925 (G-F-2) and of all elements post c. 1960 (G-F-3). The c. 1925 peak may be indicative of a catchment inwash event. EFs for P and N co-vary up-core, and are above background levels from c. 1950 (G-F-3), indicating that anthropogenic inputs became the main source of variation.

A total of 145 diatom taxa was enumerated in eight sediment samples from Bunaveela and 245 diatom taxa in 30 samples from Feeagh. Up-core variations in diatom assemblages from Bunaveela were grouped into two zones (Fig. 7). Diatom concentrations increased from c. 1970 and were coincident with a rise in abundances of Asterionella formosa, Achnanthidium minutissimum and Aulacoseira granulata. Increased abundances of Aulacoseira subarctica (to c. $40 \%$ ) distinguish diatom zone D-B-2 (the surface sample) from D-B-1. DI-TP indicates that Bunaveela has been oligotrophic (c. $10 \mu \mathrm{g} \mathrm{l}^{-1}$ ) for most of the last 100 years, although increases in DI-TP were evident from the late 1980s. For most of the record from Bunaveela, DI-pH was slightly acidic (c. 6.9), becoming less acidic from the mid 1980s. Pre-c. 1967 diatom assemblages from Feeagh (Fig. 8) and zone D-F-1, were characterised by relatively abundant $A$. minutissimum (c. 10\%), Cyclotella comensis and C. kuetzingiana, whereas c. 1967-1987 (D-F-2) was characterised by lower levels of $A$. minutissimum ( $<2 \%$ ) and increased abundances (to c. 15\%) of $A$. formosa and A. granulata, and declines in Cyclotella species. This floristic change represented a shift to species tolerant of nutrient rich conditions. Up-core variations in levels of DI-TP increased markedly from c. 1962: before this date, oligotrophic conditions are evident; whereas mesotrophic conditions $\left(\sim 15-20 \mu \mathrm{g} \mathrm{l}^{-1}\right)$ were established from the late 1960s. A sharp fall in abundances of $A$. formosa (c. 25-10\%) and increases in numbers of Achnanthes oblongella, A. granulata and A. subarctica characterise D-F-3, in which DI-TP levels also peak. Modelled DI-TP for surface sediment samples is higher than annual measured mean TP for both lakes. DI-pH shows little variation up-core, oscillating around neutral and reflecting measured $\mathrm{pH}$. Remains of cladocerans were enumerated from samples from Feeagh (Fig. 9; SD Table 4). Chydorid taxa which inhabit the littoral benthic areas of lakes were relatively abundant in the samples from the lower part of the core (pre- c. 1972), with Alona rustica accounting for more than $40 \%$ of remains in the lowermost sample examined. The uppermost samples (post c. 1972) in contrast were characterised by the planktonic taxa Daphnia and Bosmina (>65\%). The benthic/ planktonic ratio changes from 5 in the lower samples to $<1$ in the upper samples. Conifer-type pollen was evident in Bunaveela from 


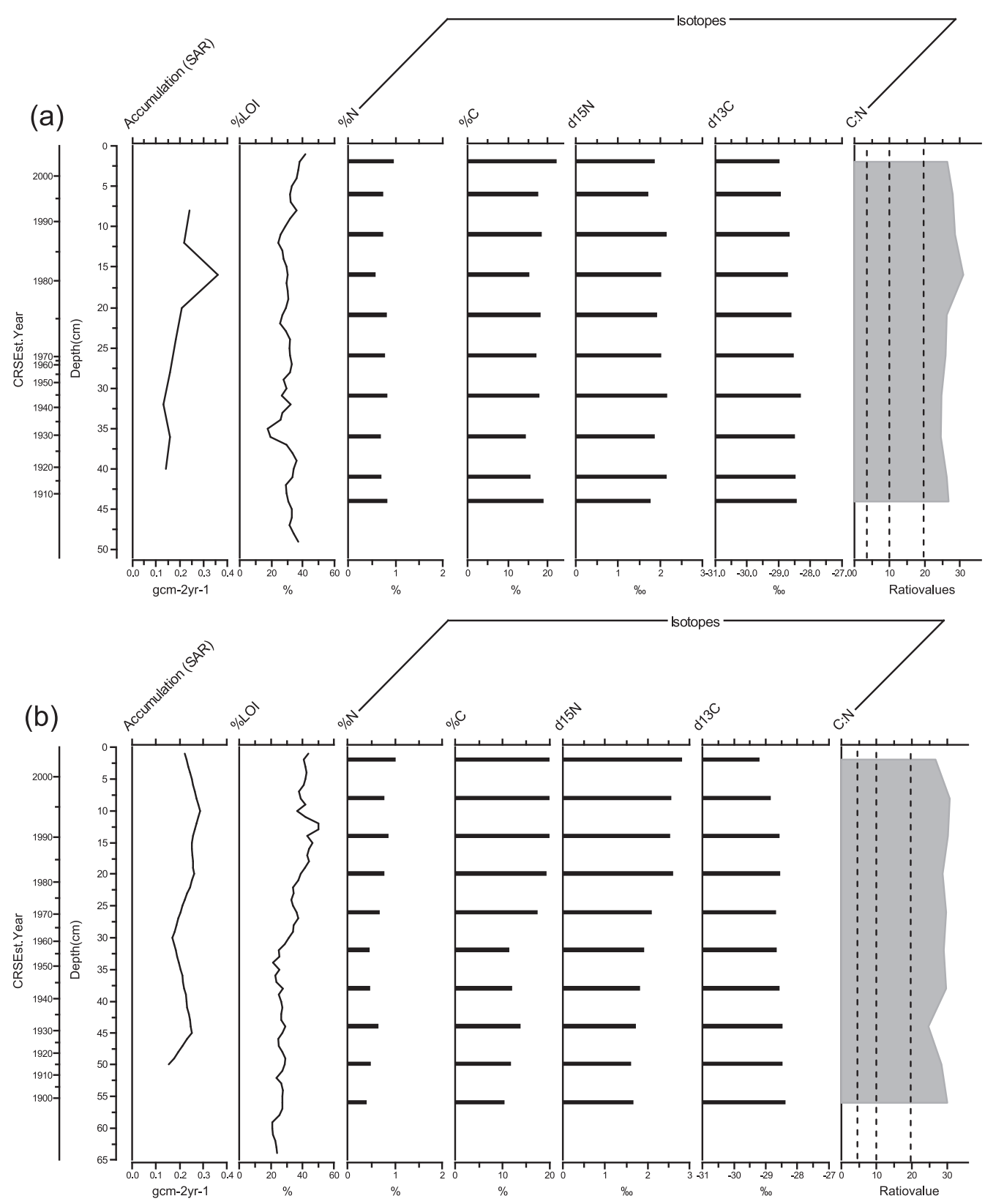

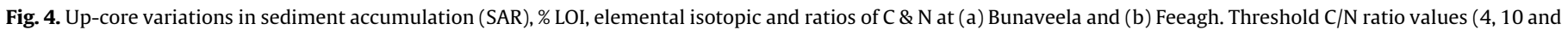
20) indicating the predominant source of organic material are represented with dashed lines (see Meyers, 2003).

c. 1970 and particularly post c. 1990 , while conifer-type and Calluna pollen increased in Feeagh from c. 1980 (Fig. 10).

\section{Statistical analysis}

An a priori selection of seven sediment response variables (SAR, \%LOI, \%C, \%N, geochemical P $\left(\mathrm{g} \mathrm{m}^{-2} \mathrm{yr}^{-1}\right)$, DI-TP and Diatom PCA Axis 1 ) and five explanatory variables (NAO, human population, livestock numbers (sheep and cattle), \% forest cover, catchment TP load) were utilised for ordination analysis of the period post-1900 in Feeagh (Fig. 11). The ordination was significant with $88 \%$ of the total variance captured by the environmental variables with axis 1 accounting for the majority (79\%) of the variation in the data. The first axis of variation was associated with livestock numbers and catchment P-loads with key sediment responses in diatom PCA axis 1 and \%C. A clear separation of pre and post-1950 samples was evident, however, must be noted that conifer forest cover in the catchment was zero before 1950 and thus may contribute to the arrangement of data points. High co-linearity is apparent in both the response and explanatory variables.

\section{Discussion}

Feeagh and Bunaveela yielded sedimentary records that facilitated the compilation of well-dated, high resolution, multiproxy evidence of past environmental conditions in the Burrishoole catchment from the late 19th century. According to the palaeolimnological records obtained, low nutrient levels prevailed in the Burrishoole catchment until the 1950s after which point nutrient enrichment and increased sedimentation occurred, evidently linked to alterations in catchment conditions and possibly enhanced by climate change. Notably DI-TP accorded with measured sediment $\mathrm{P}$ in both lakes and with modelled variations in past in-lake TP levels in Feeagh despite their different 


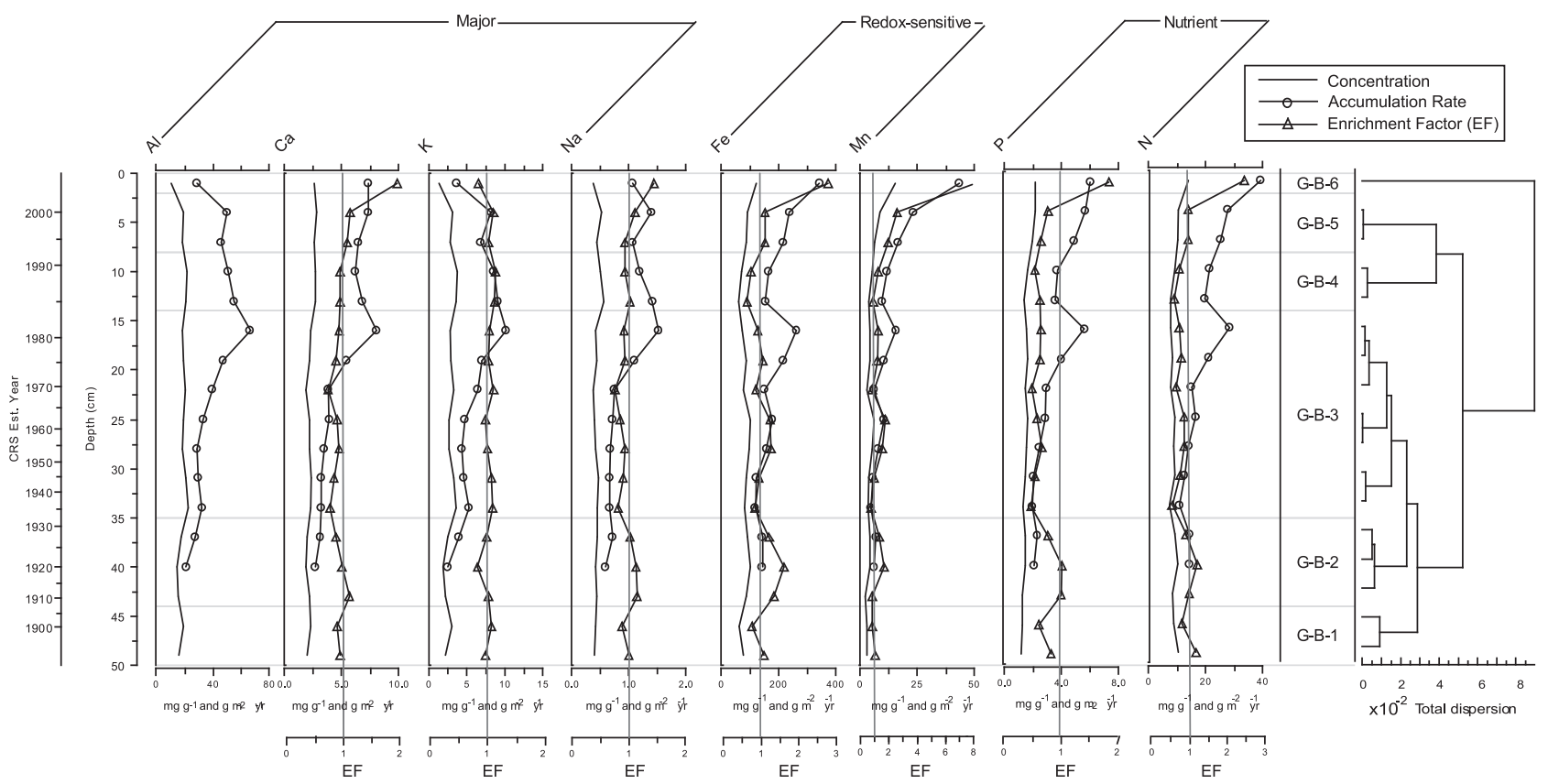

Fig. 5. Bunaveela: Concentration, accumulation rate and Enrichment Factors (EFs) for chemical elements (EFs $=1$ are highlighted).

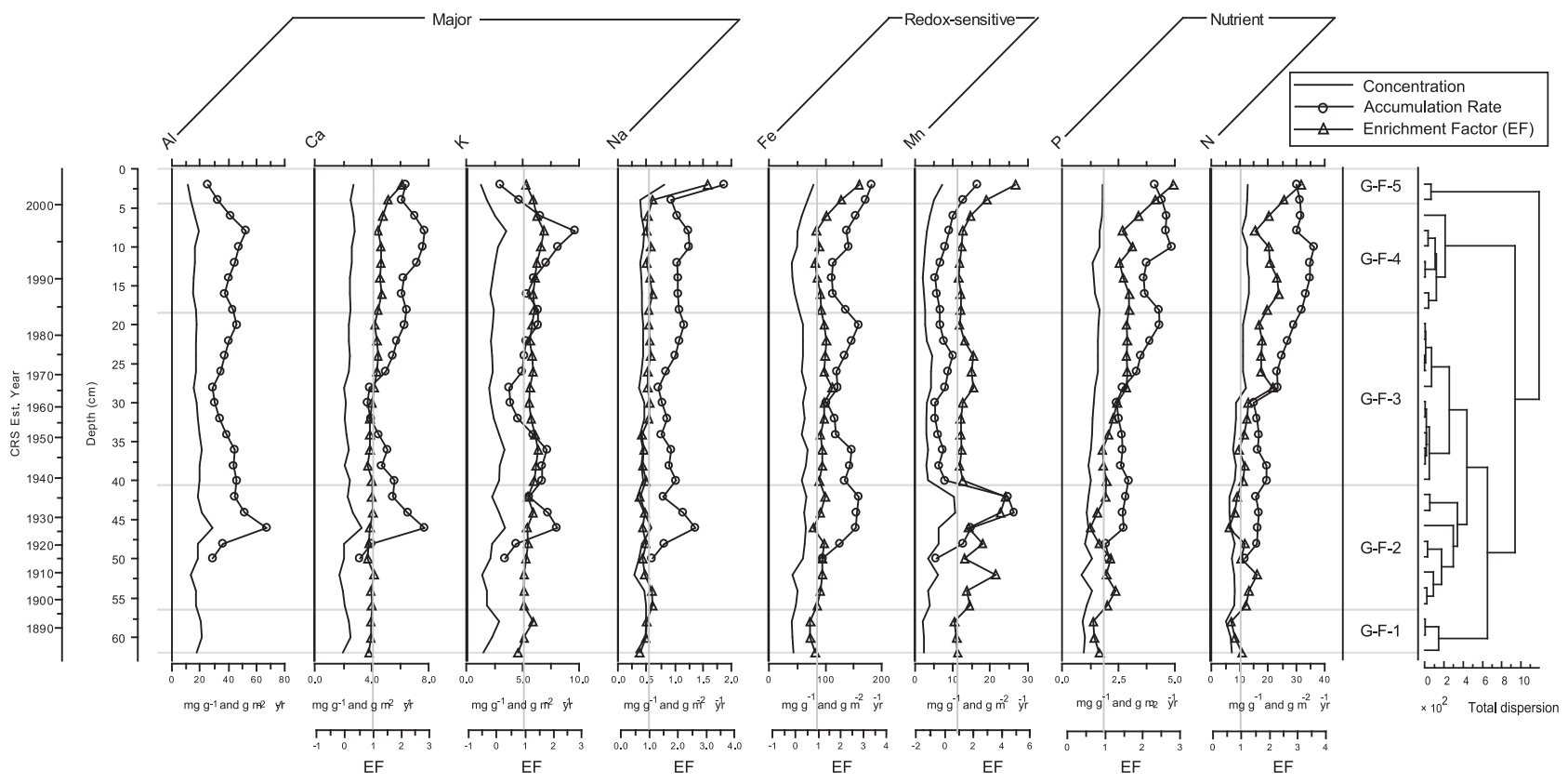

Fig. 6. Feeagh: Concentration, accumulation rate and Enrichment Factors (EFs) for chemical elements (EFs $=1$ are highlighted).

temporal resolutions. The timing of the onset of change evident in the physical, chemical and biological sediment proxies is asynchronous, with Feeagh appearing to show evidence of human impact on water quality before Bunaveela suggesting responses to different drivers within the same catchment, or different levels of sensitivity to the same pressures, or some combination of the two. The constraints of integrating palaeolimnological and observational time-series data include chronological uncertainty, sampling interval and core correlation. However, when taken together, the two sets of data appear to disprove the null hypothesis and suggests that there are strong grounds for a relationship between changing environmental conditions in an upland peat catchment and aquatic responses during the last 100 years.

\section{Catchment-based drivers of aquatic change}

Multivariate ordination confirmed that physical, chemical and biological sediment responses were related to catchment disturbance associated with commercial forestry. Afforestation has been implicated for some time as a likely pressure impacting aquatic conditions in Burrishoole (Allott et al., 2005; May et al., 2005). Afforestation targeted unproductive upland areas of the catchment (Allott and Brennan, 1993). Soils in these parts were highly susceptible to erosion, especially during initial planting and subsequent harvesting, and the results presented here indicate that the primary adverse impact was increased erosion, and downstream sedimentation. The sediment pollen record confirms 


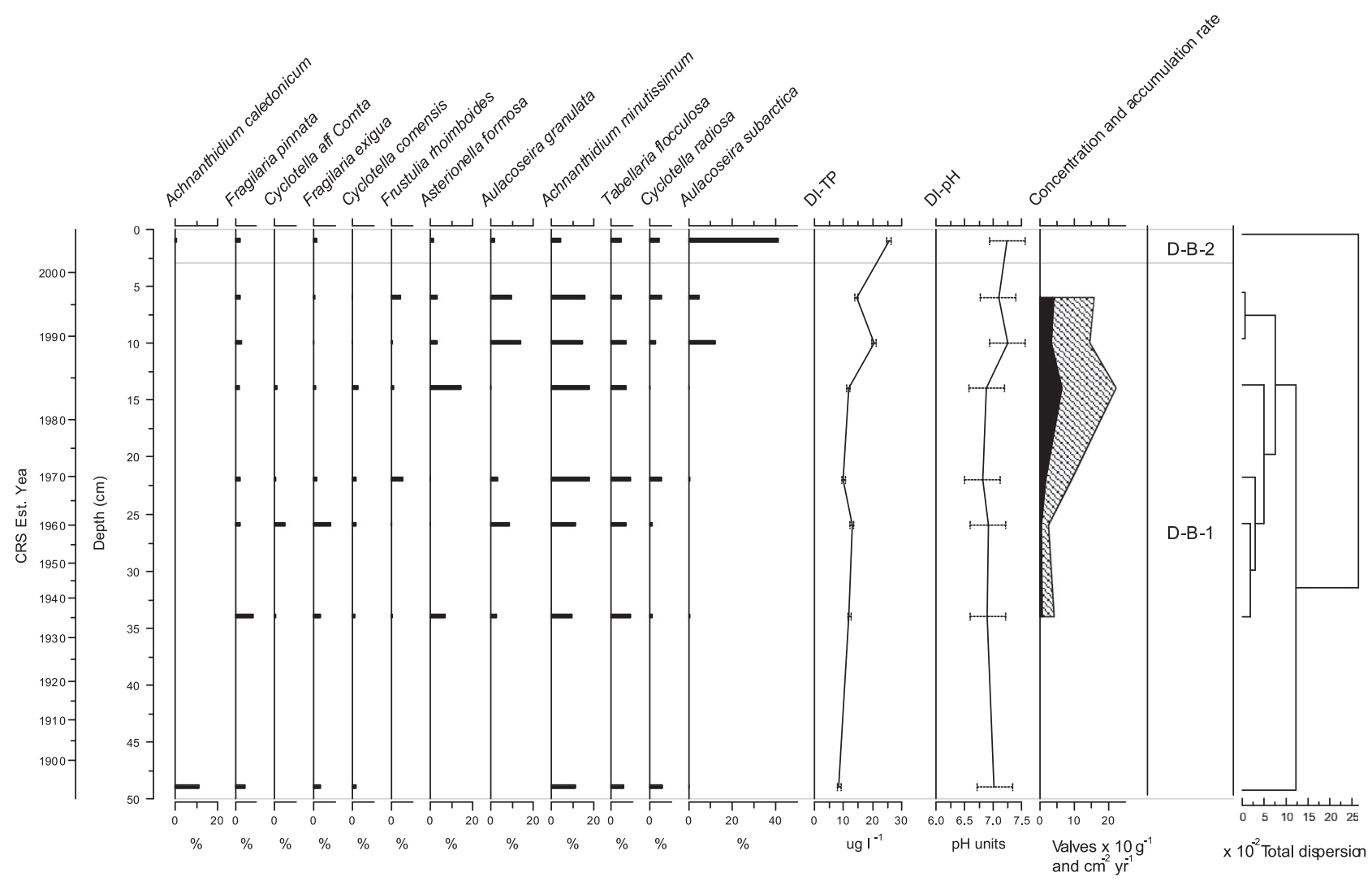

Fig. 7. Bunaveela: up-core variations in abundances of diatom remains, DI-TP and DI-pH, concentrations (black silhouette) and flux (grey silhouette).

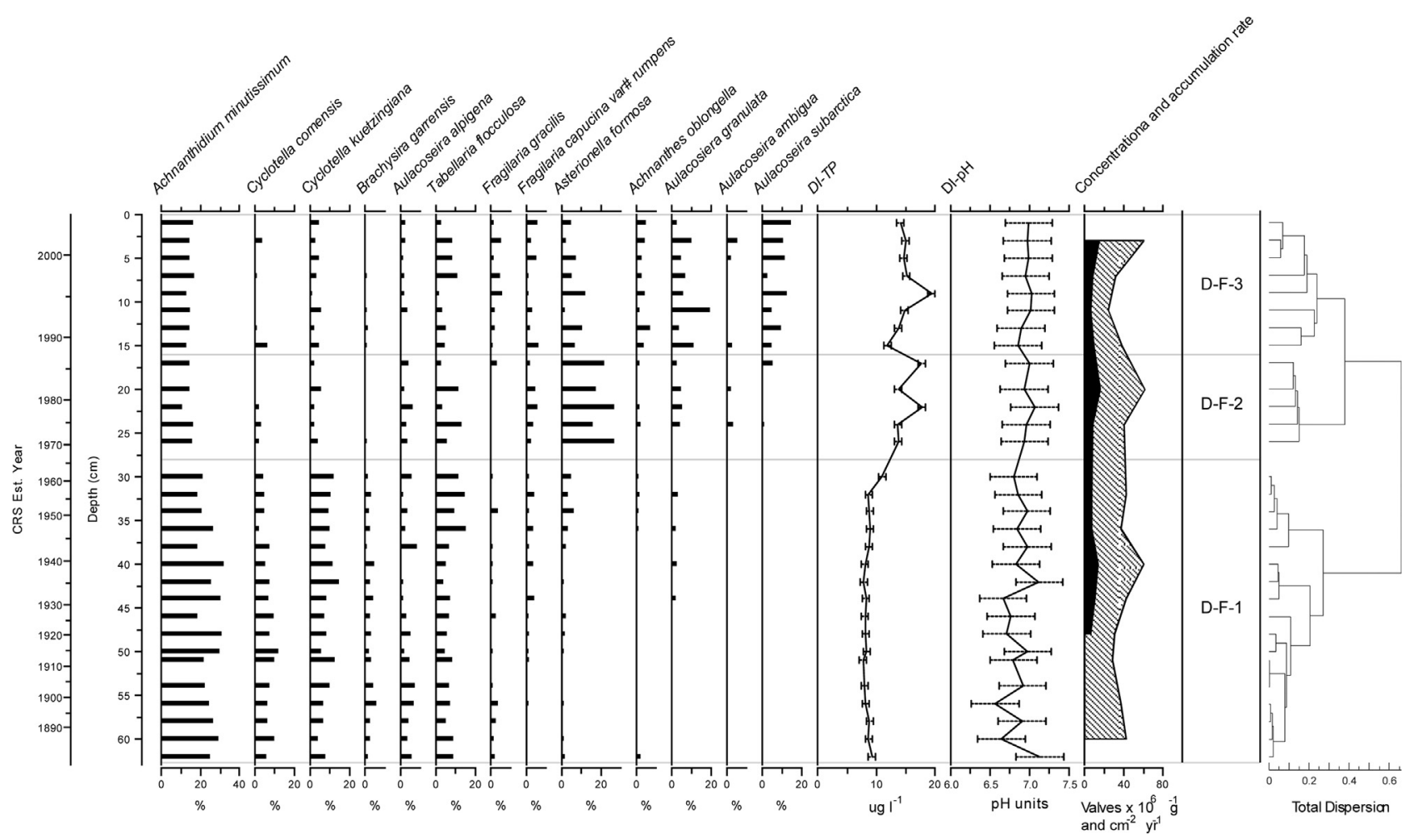

Fig. 8. Feeagh: up-core variations in diatom abundances, DI-TP and DI-pH, concentrations (black silhouette) and flux (grey silhouette).

a shift in catchment vegetation, and in particular increased conifer pollen from c. 1960 in Feeagh. Overall, ${ }^{210} \mathrm{~Pb}$-estimated levels of SAR and organic matter content increase up-core from 1960 in Feeagh and are thought likely to be the products of catchment disturbance. Isotope data, additionally, suggest that organic matter originated largely from terrestrial sources $\left(C_{3}\right.$ plants) (de Freitas et al., 2001). Acceleration of run-off materials via erosion results in an increased geochemical and nutrient input to drainage systems 


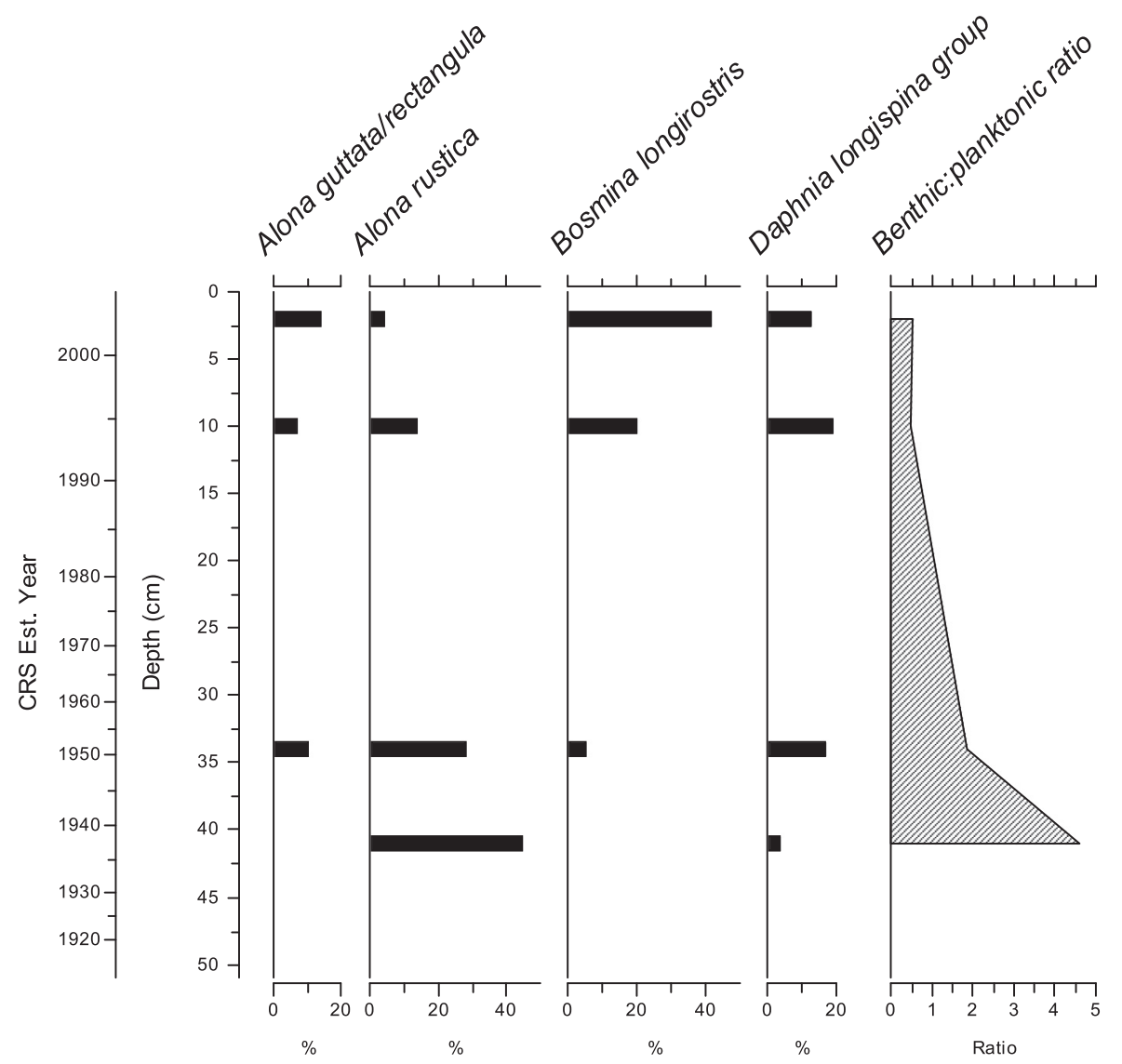

Fig. 9. Selected cladocera species/groups (\% abundance) stratigraphic and benthic/planktonic profiles from Feeagh.

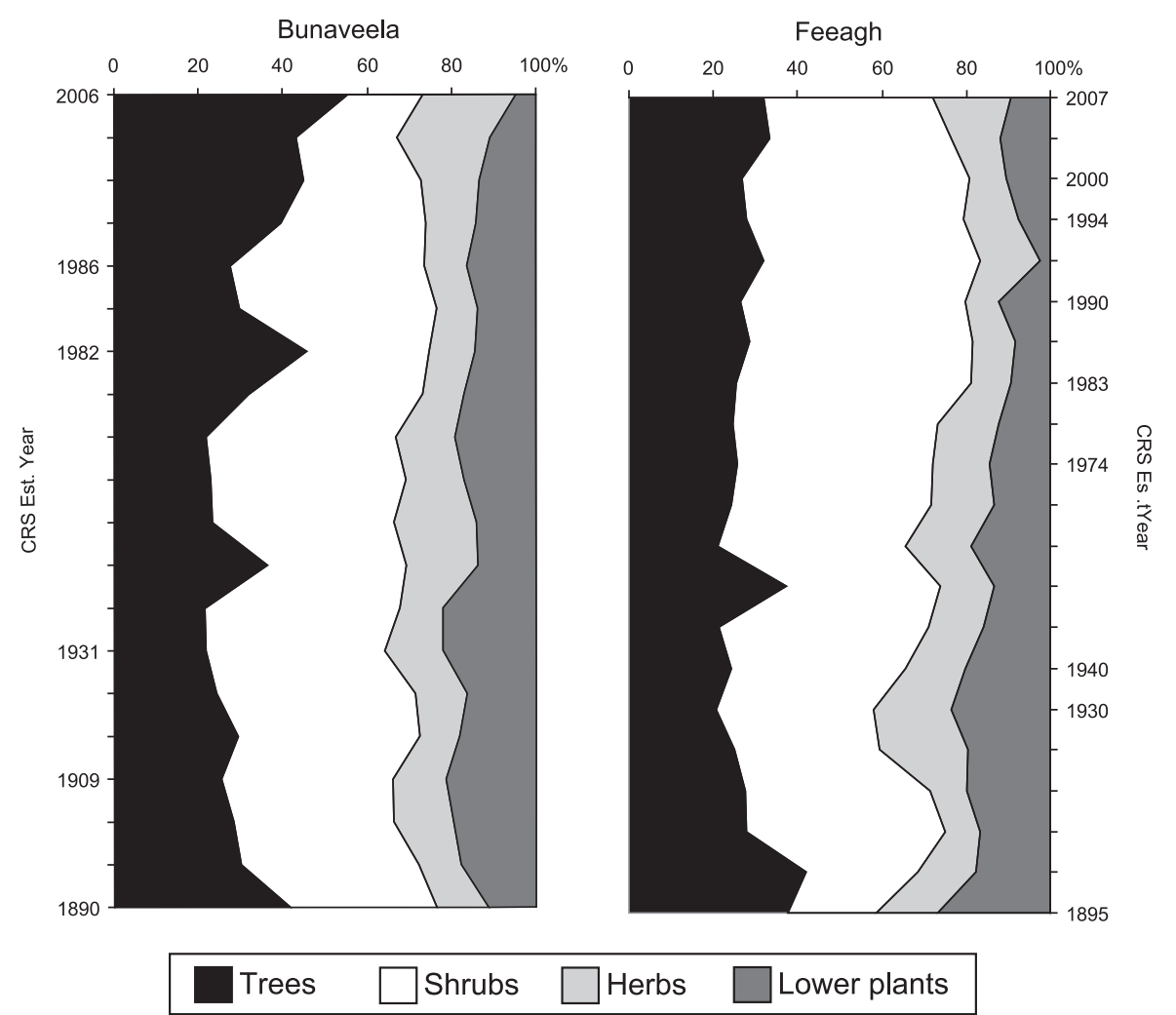

Fig. 10. Summary pollen stratigraphic profiles for Bunaveela and Feeagh. 


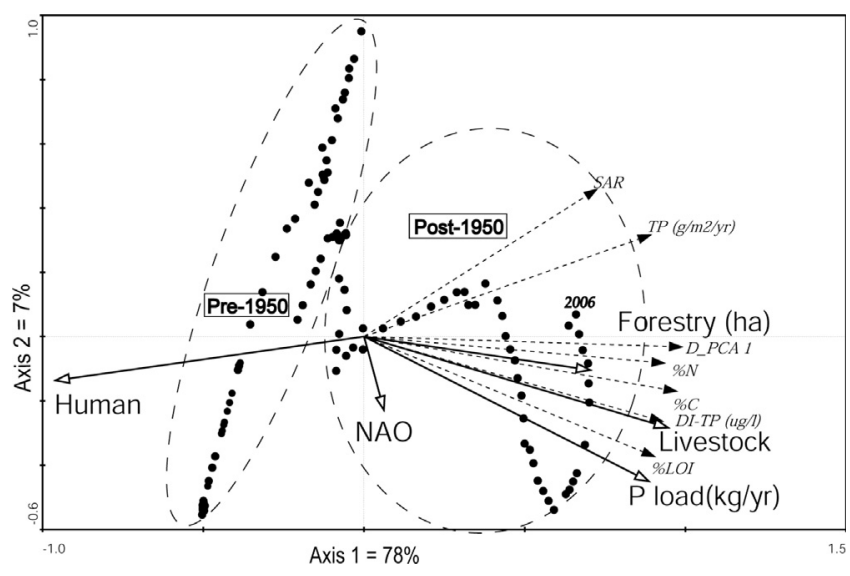

Fig. 11. RDA biplot of Feeagh sediment proxy response data ( 7 variables - dashed vectors) and possible explanatory drivers (5 variables - solid vectors). Data from 1900 AD (pre- and post-1950 annual data points (black circles) enclosed in dashedellipses).

(Cummins and Farrell, 2003; Rodgers et al., 2010; Drinan et al., 2013a). Increased $\mathrm{P}$ and $\mathrm{N}$ from c. 1960 in Feeagh are coincident with enhanced levels of $\delta^{15} \mathrm{~N}$ and anthropogenic inputs (EFs $>1$ ).

Aquatic chemical and biological responses to acidification and nutrient enrichment of surface waters draining forested catchment are long established (Ormerod et al., 1991; Allott et al., 1997; Cummins and Farrell, 2003). Acidification has been attributed to anthropogenic acid deposition and natural organic acids, both enhanced by catchment afforestation. Leira et al. (2006) discuss comparisons between the composition of uppermost and lowermost samples of lake sediment from short (c. $40-50 \mathrm{~cm}$ ) cores that suggested that over the last c. 80 years Feeagh had acidified slightly. This preliminary examination did not establish intervening trends. The more detailed biological response in the current study in terms of DI-pH shows remarkably little variation up-core in both Bunaveela and Feeagh, confirming circumneutral conditions over the last c. 120 years, and is in agreement with the findings of O'Driscoll et al. (2012), who enumerated circumneutral diatom assemblages in some inflowing streams to Lough Feeagh. Several western Ireland catchment streams, based on granite and schist, experience very low $\mathrm{pH}$ on occasion, often dipping to c. $\mathrm{pH} 4$ during floods (Fealy et al., 2010) and can therefore be regarded as sensitive to acidification pressures. However, complex interactions in humic aquatic systems, including retention of calcium in soils and DOC buffer effects, can ameliorate episodic acidification events (Aherne and Curtis, 2003; Evans et al., 2008).

A more pronounced nutrient enrichment signal was evident in the catchment sediment records. For Feeagh both qualitative and quantitative changes in the remains of diatoms are evident, with assemblages numerically dominated by oligotrophic species being replaced by those characterised by increased abundances of nutrient tolerant taxa from c. 1960 . Moreover, the remains of Cladocera extracted from sediment samples from Feeagh change from assemblages with a dominant presence of benthic species to one increasingly characterised by planktonic taxa. Changes in the relative occurrence of benthic and pelagic cladoceran taxa over time may be the result of several drivers. An increase in pelagic cladoceran taxa could indicate a top down release from fish predation as well as a bottom up response to eutrophication (Jeppesen et al., 2001). No time series data are available on the resident brown trout population to test predation causality. A reduction in the abundance of littoral benthic chydorids may also suggest a bottom up response in terms of reduced habitat (Duigan and Birks, 2000; Jeppesen et al., 2001), especially of macrophytes. The lakes currently have limited macrophyte cover possibly as result of high DOC in the water column. Sparber (2012) reports a decline in water clarity in Feeagh, and hence the depth of the euphotic zone. Additionally de Eyto et al. (2002) found a relatively depauperate cladoceran assemblage in comparison to other upland oligotrophic lakes. It is, therefore, possible that reduced water transparency and macrophyte cover could account for the decrease in the abundance of benthic cladocera reported here. Preliminary examination of littoral cores for plant macrofossils (not reported here) proved inconclusive.

Evidence of the profound aquatic effects of catchment disturbance, dating to the mid-1980s, is apparent in the sedimentary record from Bunaveela (the headwater lake in the study catchment). Afforestation of the upper part of the catchment commenced later than in lower parts, with the bulk of commercial forestry being planted in 1990. Initial catchment disturbance around Bunaveela is perhaps therefore more likely to be the result of overgrazing rather than commercial forestry operations. Overgrazing by livestock has been implicated as a pressure impacting aquatic conditions in the catchment (Allott et al., 2005; May et al., 2005). The sharp increase in sheep numbers from the mid-1970s and subsequent over-grazing of erosion-sensitive substrates are likely to have further added to sediment loadings to streams draining into the two lakes. Increased deposition of organic-rich sediments and redox-sensitive and nutrient elements are evident from the early 1980s in Bunaveela and are thought likely to be representative of a second phase of catchment disturbance. Increased levels of Mn and Fe are evident from c. 1995, with the uppermost peaks likely artefacts of redox recycling (Boyle, 2001).

The onset of mesotrophic conditions date to the late 1980s/ early 1990s. However, it must be noted that the diatom transfer function appears to overestimate in-lake levels of TP in Bunaveela. This is probably artefact of the transfer function used, e.g. the species Aulacoseira subarctica has a TP optimum of c. $29 \mu \mathrm{g} \mathrm{l}^{-1}$ (Chen et al., 2008) and is a key driver of the DI-TP increase. The current TP estimate for Feeagh of c. $14 \mu \mathrm{g} \mathrm{l}^{-1} \mathrm{TP}$ is reasonable and provides a basis for confidence in the reconstruction.

Afforestation and over-grazing land use changes identified in this study have clearly resulted in episodically produced anthropogenic sediment or legacy sediment (James, 2013). Sediment has accumulated in the downstream lakes at rates exceeding that of natural conditions. In the Burrishoole catchment, Feeagh and Bunaveela operated as the main sinks for sediment during the second half of the 20th century. Recent palaeolimnological work on Lough Furnace, which is a coastal lagoon immediately downstream of Feeagh, indicated that very little of this sediment has reached the marine environment. Sediment accumulation rates for Lough Furnace were c. $0.03 \mathrm{~g} \mathrm{~cm}^{-2} \mathrm{yr}^{-1}$ (Cassina et al., 2013), an order of magnitude less than the SARs recorded here for Feeagh and Bunaveela. The basin morphology of Feeagh (deep water, with a glacially exposed ridge of albite schist separating it from Furnace (Synge, 1963)) presumably limits the amount of sediment leaving the lake in suspension, with the majority sinking to the bottom as it travels the length of the lake.

\section{Climate-driven change}

While ordination analysis did not directly implicate climate as a driver of aquatic changes in Feeagh, results suggest a role for NAO. The early part of the sediment records (1890-1930) collected from both Feeagh and Bunaveela were associated with a positive NAO index, and are coincident with increasing rates of sediment accumulation and relatively constant rates of nutrient enrichment. This was a period of minimal human impact (although human population levels were higher) at the site: increased SARs may have resulted from increased catchment erosion due to increased levels of precipitation associated with a strong positive phase of 
the NAO (Jennings et al., 2000). From 1930, a decrease in SAR is apparent at both sites, persisting at Bunaveela until the early 1940s and at Feeagh until the mid-1960s. From the mid-1960s, SAR began to increase at both sites, earlier than would have been expected had it been influenced by the NAO alone. A strong negative phase of the NAO, associated with cooler temperatures, decreased wind speeds and rainfall, occurred between the 1940s and 1970s (Jennings et al., 2000) and would likely have resulted in reduced sediment accumulation. Increasing human impact would have masked any sedimentary signal of the NAO in this period. Cattle numbers in the catchment increased from the 1930s, but remained relatively low. However, afforestation of the catchment, commencing in 1950 and increasing in extent during 1960-1969, would likely have resulted in enhanced SAR.

\section{Implications for the objectives of the WFD}

Reference status, i.e. conditions showing no or minimal anthropogenic impact, can be established for aquatic systems in several ways (Andersen et al., 2004), including palaeolimnological approaches. Palaeolimnology provides a means of not just determining anthropogenically-induced effects, however; lake sediments also provide a basis for unravelling the multitude of drivers and pressures (Smol, 2010). Palaeolimnological research confirmed the current reference status of a selection of oligotrophic and meso-oligotrophic lakes in Ireland (Leira et al., 2006). These lakes are in catchments where humaninduced drivers of aquatic ecosystem changes are thought to be minimal. By contrast, evidence assembled in this paper indicates that the oligotrophic lakes Bunaveela and Feeagh have been impacted by human-related activities, with the effects on Bunaveela beginning later and in a more subdued form than Feeagh. The main drivers in both cases appear to be catchment erosion and nutrient enrichment associated with afforestation from the 1950s and over-grazing from the 1980s, with their aquatic impacts possibly enhanced by climate change. The sedimentary evidence therefore provides confirmation of an earlier claim that current conditions in Feeagh are nutrient enriched relative to reference state (Leira et al., 2006). This detailed reconstruction of historical responses in the last century provides a qualitative and quantitative record of spatial and temporal responses to catchment pressure and calls into question the characterisation of Feeagh as 'probably not at significant risk' of meeting the requirements of the WFD (Anon., 2005). Our data suggest that characterisation of risk status based on limited available data is problematic and that data from oligotrophic headwater systems may warrant further inquiry. While there is a clear need for lake classification schemes for administrative purposes, caution is required in determining target conditions for lake management. This is also important when considering the potential impacts of climate change on the lake systems.

\section{Conclusion}

The evidence provided here shows clear links between driver and response data for an internationally important oligotrophic catchment on the Atlantic seaboard of western Europe and gives some indication why the area is not classified as 'high' ecological status. It is likely that the catchment changes and aquatic impacts associated with erosion and nutrient enrichment described in the paper have impacted the fish populations. This case study has provided valuable information on the spatial and temporal scales of effect of catchment use on sensitive freshwater ecosystems and serves as a basis for further investigations into fish populations along with other possible drivers.

\section{Acknowledgements}

We would like to thank the Environmental Protection Agency in Ireland for funding this project (ILLUMINATE \# 2005-W-MS-40), Alice Wemaëre and external members of the project steering committee for their guidance and support throughout the research. P. McGinnity was supported by the Beaufort Marine Research Award in Fish Population Genetics funded by the Irish Government under the Sea Change Programme. Thanks are also due to several colleagues for their assistance with field and laboratory work; Marzena Olas and Kim Olaya-Bosch for help in the field and the pollen analysis; Aine Gormley, Fergel Nugent and Theresa Hughes for help with geochemical analysis; and particularly the staff of the Marine Institute (Newport) who facilitated the collection of the field data (lake cores) and the census data.

\section{Appendix A. Supplementary data}

Supplementary material related to this article can be found, in the online version, at doi:10.1016/j.ancene.2014.06.003.

\section{References}

Aherne, J., Curtis, J.C., 2003. Critical loads of acidity for Irish lakes. Aquat. Sci. 65, $21-35$.

Allott, N., Brennan, M., Cooke, D., Reynolds, J., Simon, N., 1997. AQUAFOR Report 4. Stream Chemistry, Hydrology and Biota Galway-Mayo region. A Study of the Effects of Stream Hydrology and Water Chemistry in Forested Catchments on Fish and Macroinvertebrates COFORD, Dublin, Ireland, pp. 1-158.

Allott, N., Mills, W.R.P., Dick, J.R.W., Eacrett, A.M., Brennan, M.T., Clandillon, S., 1990. Acidification of surface waters in Connemara and South Mayo. Current status and causes du Quesne Limited, Economic and Environmental Consultants, Dublin, pp. 61.

Allott, N., Brennan, M., 1993. Stream chemistry and biota, Galway-Mayo Region. Evaluation of the Effects of Forestry on Surface-Water Chemistry and Fishery Potential in Ireland, vol. 2. Eolas, Dublin, 109 pp.

Allott, N., McGinnity, P., O'Hea, B., 2005. Factors influencing the downstream transport of sediment in the Lough Feeagh catchment Burrishoole, Co. Mayo, Ireland. Freshw. Forum 23, 126-213.

Andersen, J.H., Conley, D.J., Hedal, S., 2004. Palaeoecology, reference conditions and classification of ecological status: the EU Water Framework Directive in practice. Mar. Pollut. Bull. 49, 283-290.

Anon., 2005. Article 5. The characterisation and analysis of Ireland's river basin districts. In accordance with Section 7 ( 2 \& 3) of the European Communities (Water Policy) Regulations 2003 (SI 722 of 2003). National Summary Report (Ireland) Compendium of public submissions and responses.

Appleby, P.G., 2001. Chronostratigraphic techniques in recent sediments. In: Last, W.M., Smol, J.P. (Eds.), Tracking Environmental Change Using Lake Sediments. Vol. 1: Basin Analysis, Coring and Chronological Techniques. Kluwer Academic Publishers, Dordrecht, The Netherlands, pp. 155-202.

Battarbee, R.W., Grytnes, J.A., Thompson, R., Appleby, P.G., Catalan, J., Korhola, A., Birks, H.J.B., Heegaard, E., Lami, A., 2002. Comparing palaeolimnological and instrumental evidence of climate change for remote mountain lakes over the last 200 years. J. Paleolimnol. 28, 161-179.

Battarbee, R., Carvalho, L., Jones, V.J., Flower, R.J., Cameron, N.G., Bennion, H., Juggins, S., 2001. Diatoms. In: Smol, J.P., Birks, H.J.B., Last, W.M. (Eds.), Tracking Environmental Change Using Lake Sediments, Vol. 3: Terrestrial, Algal and Siliceous Indicators. Kluwer Academic Publishers, Amsterdam, pp. 155-202.

Bennett, K.D., 1996. Determination of the number of zones in a biostratigraphic sequence. New Phytol. 132, 155-179.

Bennett, K.D., Willis, K.J., 2001. Pollen. In: Smol, J.P., Birks, H.J.B., Last, W.M. (Eds.), Tracking Environmental Change Using Lake Sediments. Vol. 3 Terrestrial, Algal and Siliceous Indicators. Kluwer Academic Publishers, Amsterdam, pp. 5-32.

Bennion, H., Fluin, J., Simpson, G.L., 2004. Assessing eutrophication and reference conditions for Scottish freshwater lochs using subfossil diatoms. J. Appl. Ecol. 41, 124-138.

Binford, M.W., 1990. Calculation and uncertainty analysis of $210 \mathrm{~Pb}$ dates for PIRLA project lake sediment cores. J. Paleolimnol. 3, 253-267.

Birks, H.J.B., Lotter, A.F., Juggins, J., Smol, J.P., 2012. Tracking Environmental Change Using Lake Sediments: Data Handling and Numerical Techniques. Developments in Paleoenvironmental Research, Vol. 5 of Tracking Environmental Change Using Lake Sediments Kluwer Academic Publishers, Amsterdam.

Black, K., O'Brien, P., Redmond, J., Barrett, F., Twomey, M., 2008. The extent of recent peatland afforestation in Ireland. Ir. Forestry 65 (1\&2) 71-81.

Bock, R., 1979. A Handbook of Decomposition Methods in Analytical Chemistry. International Textbook Co., Glasgow.

Boyle, J.F., 2001. Inorganic geochemical methods in palaeolimnology. In: Last, W.M., Smol, J.P. (Eds.), Tracking Environmental Change Using Lake Sediments, Vol. 2. 
Physical and Geochemical Methods. Kluwer, Dordecht, The Netherlands, pp. 83-141.

Carling, P.A., Irvine, B.J., Hill, A., Wood, M., 2001. Reducing sediment inputs to Scottish streams: a review of the efficacy of soil conservation practices in upland forestry. Sci. Total Environ. 265 (1) 209-227.

Cassina, F., Dalton, C., Dillane, M., DeEyto, E., 2013. A multi-proxy palaeolimnological study to reconstruct the evolution of a coastal brackish lake (Lough Furnace, Ireland) during the late-Holocene. Palaeogeogr. Palaeoclimatol. Palaeoecol. 383-384, 1-15.

Cerling, T.E., 1999. Paleorecords of C4 plants and ecosystems. In: Sage, R.F., Monson, R.K. (Eds.), C4 Plant Biology. Academic Press, London, pp. 445-469.

Chen, G., Dalton, C., Leira, M., Taylor, D., 2008. Construction of diatom-inferred pH and total phosphorus (TP) transfer functions for the Irish Ecoregion using palaeolimnological techniques. J. Paleolimnol. 40, 143-163.

Cole, J.J., Carpenter, S.R., Kitchell, J., Pace, M.L., Solomon, C.T., Weidel, B., 2011. Strong evidence for terrestrial support of zooplankton in small lakes based on stable isotopes of carbon, nitrogen, and hydrogen. Proc. Natl. Acad. Sci. U.S.A. 108, 1975-1980.

Crozier, W.W., Potter, E.C.E., Prévost, E., Schon, P.-J., Ó Maoiléidigh, N., 2003. A coordinated approach towards the development of a scientific basis for management of wild Atlantic salmon in the north-east Atlantic (SALMODEL - Scientific Report Contract QLK5-1999-01546 to EU Concerted Action Quality of Life and Management of Living Resources). Queen's University of Belfast, Belfast, pp. 431.

Cruikshanks, R., Lauridsen, R., Harrison, A., Hartl, M.G.J., Kelly-Quinn, M., O’Halloran, J., 2008. Putting the Sodium Dominance Index to the test as a measure of acid sensitivity across diverse geological conditions and with reference to the influence of plantation forests. Water Air Soil Pollut. 190, 221-229.

Cummins, T., Farrell, E.P., 2003. Biogeochemical impacts of clearfelling and reforestation on blanket peatland streams I. phosphorus. For. Ecol. Manage. 180 (13) $545-555$

Dalton, C., 2000. Organic Acidity in Lake Waters in Connemara, W. Ireland: A Preliminary Investigation Using Diatom Analysis, vol. 27. Verhandlungen Internationale Vereinigung für Theoretische und Angewandte Limnologie, , pp. 1193-1198.

Dalton, C., Jennings, E., Taylor, D., 2009. Palaeolimnology and the water framework directive. Biol. Environ. Proc. R. Ir. Acad. 109B (special issue (3)) 161-174.

de Eyto, E., Irvine, K., Free, G., 2002. The use of members of the family Chydoridae (Anomopoda, Branchiopoda) as an indicator of lake ecological quality in Ireland. Biol. Environ. Proc. R. Ir. Acad. 102, 81-91.

de Freitas, H.A., Pessenda, L.C.R., Aravena, R., Gouveia, S.E.M., Ribeiro, Ad-S., Boulet, R., 2001. Late quaternary vegetation dynamics in the southern Amazon basin inferred from carbon isotopes in soil organic matter. Quat. Res. 55, 39-46.

Drinan, T.J., Graham, C.T., O'Halloran, J., Harrison, S.S.C., 2013a. The impact of conifer plantation forestry on the Chydoridae (Cladocera) communities of peatland lakes. Hydrobiologia 700, 203-219.

Drinan, T.J., Graham, C.T., O'Halloran, J., Harrison, S.S.C., 2013b. The impact of catchment conifer plantation forestry on the hydrochemistry of peatland lakes. Sci. Total Environ. 443, 08-620.

Duigan, C., Birks, H.H., 2000. The late-glacial and early-Holocene palaeoecology of cladoceran microfossil assemblages at Kråkenes, western Norway, with a quantitative reconstruction of temperature changes. J. Paleolimnol. 23, 67-76.

Evans, C.D., Monteith, D.T., Reynolds, B., Clark, J.M., 2008. Buffering of recovery from acidification by organic acids. Sci. Total Environ. 404, 316-325.

Fealy, R., Allott, N., Broderick, C., de Eyto, E., Dillane, M., Erdil, R.M., Jennings, E., McCrann, K., Murphy, C., O’Toole, C., Poole, R., Rogan, G., Ryder, E., Taylor, D., Whelan, K., White, J., 2010. RESCALE: Review and Simulate Climate and Catchment Responses at Burrishoole, Final Summary Report, Marine Research Sub Programme 2007-2013. Marine Institute, Oranmore. Co., Galway, pp. 1-126 ISSN 2009-3195.

Feeley, H.B., Kerrigan, C., Fanning, P., Hannigan, E., Kelly-Quinn, M., 2011. Longitudinal extent of acidification effects of plantation forest on benthic macroinvertebrate communities in soft water streams: evidence for localised impact and temporal ecological recovery. Hydrobiologia 671, 217-226.

Frey, D.G., 1986. Cladocera analysis. In: Berglund, B.E. (Ed.), Handbook of Holocene Paleoecology and Paleohydrology. John Wiley and Sons, Chichester, UK, pp. 667-692.

Gillmor, D.A., Walsh, J.A., 1993. County level variations in agricultural adjustment in Ireland in the 1980s. Geogr. Viewp. 21, 25-44.

Gordon, J.E., Brazier, V., Thompson, D.B.A., Horsfield, D., 2001. Geo-ecology and the conservation management of sensitive upland landscapes in Scotland. Catena 42, 323-332.

Grimm, E.C., 1987. CONISS: a fortran 77 programme for stratigraphically constrained cluster analysis by the method of incremental sum of squares. Comput. Geosci. 13, 13-35.

Heaney, S.I., Foy, R.H., Kennedy, G.J.A., Crozier, W.W., O’Connor, W.C.K., 2001 Impacts of agriculture on aquatic systems: lesson learnt and new unknowns in Northern Ireland. Mar. Freshw. Res. 52, 151-163.

Heiri, O., Lotter, A.F., Lemcke, G., 2001. Loss on ignition as a method for estimating organic and carbonate content in sediments: reproducibility and comparability of results. J. Paleolimnol. 25, 101-110.

Hendry, K., Cragg-Hine, D., O'Grad, M., Sambrook, H., Stephen, A., 2003. Management of habitat for rehabilitation and enhancement of salmonid stocks. Fish. Res. 62 (2) 171-192.

Hurrell, J.W., 1995. Decadal trends in the North Atlantic oscillation. Science 269, 676-679.
ICES, 2012. Report of the Joint EIFAAC/ICES Working Group on Eels (WGEEL), 3-9 September 2012. ICES CM 2012/ACOM:18, Copenhagen, Denmark 824 pp.

ICES, 2013. Report of the Working Group on North Atlantic Salmon (WGNAS), 3-12 April 2013. ICES CM 2013/ACOM:09, Copenhagen, Denmark 380 pp.

Jasser, I., Arvola, L., 2003. Potential effects of abiotic factors on the abundance of autotrophic picoplankton in four boreal lakes. J. Plankton Res. 25, 873-883.

James, L.A., 2013. Legacy sediment: definitions and processes of episodically produced anthropogenic sediment. Anthropocene, http://dx.doi.org/10.1016/ j.ancene.2013.04.001.

Jennings, E., NicAonghusa, C., Allott, N., Naden, P., O'Hea, B., Pierson, D., Schneiderman, E., 2010. Future climate change and water colour in Irish peatland catchments: results from the CLIME project. In: Proceedings of National Hydrology Seminar Water Resources in Ireland and Climate Change.

Jennings, E., Allott, N., McGinnity, P., Poole, R., Quirke, B., Twomey, H., George, D.G., 2000. The North Atlantic Oscillation: implications for freshwater systems in Ireland. Biol. Environ. 100B, 149-158.

Jeppesen, E., Leavitt, P., De Meester, L., Jensen, J.P., 2001. Functional ecology and palaeolimnology: using cladoceran remains to reconstruct anthropogenic impact. Trends Ecol. Evol. 16, 191-198.

Johnes, P.J., 1996. Evaluation and management of the impact of land use change on the nitrogen and phosphorus load delivered to surface waters: the export coefficient modelling approach. J. Hydrol. 183, 323-349.

Juggins, S., 2003. C2 Software for ecological and palaeoecological data analysis and visualisation. User guide Version 1.3 Newcastle University, Newcastle upon Tyne.

Kelly, F., Connor, L., Wightman, G., Matson, R., Morrissey, E., O'Callaghan, R., Feeney, R., Hanna, G., Rocks, K., Gallagher, C., 2009. Sampling for fish for the Water Framework Directive - a summary of the CFB surveillance monitoring for fish in lakes rivers and transitional waters 2007-2009. The Central and Regional Fisheries Boards, , pp. 163.

Kelly-Quinn, M., Tierney, D., Coyle, C., Bracken, J.J., 1996. Factors affecting the susceptibility of Irish soft-water streams to forest-mediated acidification. Fish. Manage. Ecol. 3, 287-301.

Kelly-Quinn, M., Tierney, D., Coyle, S., Bracken, J.J., 1997. Stream Chemistry, Hydrology and Biota, Wicklow Region. A Study of the Effects of Stream Hydrology and Water Quality in Forested Catchments on Fish and Invertebrates COFORD, Dublin, Ireland, pp. 92.

Kowalik, R.A., Ormerod, S.J., 2006. Intensive sampling and transplantation experiments reveal continued effects of episodic acidification on sensitive stream invertebrates. Freshw. Biol. 51, 180-191.

Kowalik, R.A., Cooper, D.M., Evans, C.D., Ormerod, S.J., 2007. Acidic episodes retard the biological recovery of upland British streams from chronic acidification. Global Change Biol. 13, 2439-2452.

Krammer, K., Lange-Bertalot, H., 1986-1991. Bacillariophyceae. In: Ettl, H., Gerloff, J., Heynig, H., Mollenhauer, D. (Eds.), Süßwasserflora von Mitteleuropa. FischerVerlag, Stuttgart.

Kroglund, F., Rosseland, B.O., Teien, H.-C., Salbu, B., Kristensen, T., Finstad, B., 2007 Water quality limits for Atlantic salmon (Salmo salar L.) exposed to short term reductions in $\mathrm{pH}$ and increased aluminum simulating episodes. Hydrol. Earth Syst. Sci. Discuss. 4 (5) 3317-3355.

Leira, M., Jordan, P., Taylor, D., Dalton, C., Bennion, H., Irvine, K., 2006. Recent histories of the main types of candidate reference lakes in Ireland: a palaeolimnological approach. J. Appl. Ecol. 43, 816-827.

Lohse, L., Kloosterhuis, R.T., de Stigter, H.C., Helder, W., van Raaphorst, W., van Weering, T.C.E., 2000. Carbonate removal by acidification causes loss of 20 nitrogenous compounds in continental margin sediments. Mar. Chem. 69 (193) 201.

Mainstone, C.P., Dils, R.M., Withers, P.J.A., 2008. Controlling sediment and phosphorus transfer to receiving waters - a strategic management perspective for England and Wales. J. Hydrol. 350, 131-143.

May, L., Place, C., O’Hea, B., Lee, M., Dillane, M., McGinnity, 2005. Modelling soil eroision and transport in the Burrishoole catchment, Newport, Co. Mayo, Ireland. Freshw. Forum 23, 139-154.

Meyers, P.A., 2003. Applications of organic geochemistry to paleolimnological reconstruction: a summary of examples from the Laurentian Great Lakes. Org. Geochem. 34, 261-289.

McGarrigle, M.L., Lucey, J., O'Cinnéide, M., 2010. Water Quality in Ireland 20072009. Environmental Protection Agency, Wexford, Ireland, ISBN: 978-1-84095387-9.

Moore, P.D., Webb, J.A., Collinson, M.E., 1991. Pollen Analysis. Blackwell, London.

Moriarty, C., Dekker, W. (Eds.), 1997. Management of European eel fisheries. Irish Fish. Bulletin, p. 15.

Müller, M., 2000. Hydro-geographical studies in the Burrishoole catchment, Newport, Co. Mayo, Ireland: affects of afforestation on the run-off regime of small mountain spate river catchments. Verhandlung Internationale Vereinigung Limnologie 27, 1146-1148.

Naden, P., Allott, N., Arvola, L., Jarvinen, M., Jennings, E., Moore, K., Nic Aongusa, C., Pierson, D., Schneidermen, E., 2010. Modelling the effects of climate change on dissolved organic carbon. In: George, D.G. (Ed.), The Impact of Climate Change on European Lakes. Springer.

Norton, S.A., Bienert Jr., R.W., Binford, M.W., Kahl, J.S., 1992. Stratigraphy of total metals in PIRLA sediment cores. J. Paleolimnol. 7, 191-214.

O'Connor, M., 2000. Action Plan for Blanket Bog and Wet Heath: Technical Aspects. Draft report to NPWS Dept. Environment, Heritage and Local Government, Dublin, Ireland. 
O’Driscoll, C., de Eyto, E.R., odgers, M., O’Connor, M., Asam, Z., Xiao, L., 2012. Diatom assemblages and their associated environmental factors in upland peat forest rivers. Ecol. Indic. 18, 443-451.

O'Dwyer, B., Taylor, D., 2010. Variations in levels of depositions of atmosphereborne industrial pollutants at three oligotrophic lakes in Ireland over the las 50-150 years: sediment-based archives of sources, levels and ecological sensitivity. J. Paleolimnol. 44, 123-142.

O'Keeffe, C., Dromey, M., 2004. Designation of sites for fish under the EU Habitats Directive. Biol. Environ. Proc. R. Ir. Acad. 104b (3) 103-105.

Ormerod, S.J., Durance, I., 2009. Restoration and recovery from acidification in upland Welsh streams over 25 years. J. Appl. Ecol. 46 (1) 164-174.

Ormerod, S.J., Dobson, M., Hildrew, A.G., Townsend, C.R., 2010. Multiple stressors in freshwater ecosystems. Freshw. Biol. 55 (Suppl. 1) 1-4.

Ormerod, S.J., Rutt, G., Weatherley, N.S., Wade, K., 1991. Detecting and managing the influence of forestry on river systems in Wales: results from surveys, experiments and models. In: Steer, M.W. (Ed.), Irish Rivers: Biology and Management. Royal Irish Academy, Dublin, pp. 163-184.

Renberg, I., Hansson, H., 2008. The HTH sediment corer. J. Paleolimnol. 40, 655-659.

Rodgers, M., O'Connor, M., Healy, M.G., O’Driscoll, C., Asama Z-u-Z, Nieminen, M., 2010. Phosphorus release from forest harvesting on an upland blanket peat catchment. For. Ecol. Manage. 260, 2241-2248.

Smol, J.P., 2010. The power of the past: using sediments to track multiple stressors on lake ecosystems. Freshw. Biol. 55 (Suppl. 1) 43-59.

Soulsby, C., Youngson, A.F., Moir, H.J., Malcolm, I.A., 2001b. Fine sediment influence on salmonid spawning habitat in a lowland agricultural stream: a preliminary assessment. Sci. Total Environ. 265, 295-307.

Soulsby, C., Langan, S.J., Neal, C., 2001a. Environmental change, land use and water quality in Scotland: current issues and future prospects. Sci. Total Environ. 265 (1) $387-394$.

Sparber, K., 2012. Neo- and palaeolimnological investigations in a humic and a clear water lake in the west of Ireland (unpublished Ph.D. thesis) University of Limerick.

Stefánsson, A., Gunnarsson, I., Giroud, N., 2007. New methods for the direct determination of dissolved inorganic, organic and total carbon in natural waters by Reagent-Free Ion Chromatography and inductively coupled plasma atomic emission spectrometry. Anal. Chim. Acta 582 (1) 69-74.

Strayer, D.L., Dudgeon, D., 2010. Freshwater biodiversity conservation: recent progress and future challenges. J. N. Am. Benthol. Soc. 29 (1) 344-358.

Sucker, C., Krause, K., 2010. Increasing dissolved organic carbon concentrations in freshwater: what is the actual driver? Biogeosci. For. 3, 103-108.

Suttle, K.B., Power, M.E., Levine, J.M., McNeely, C., 2004. How fine sediment in riverbeds impairs growth and survival of juvenile salmonids. Ecol. Appl. 14, 969-974.

Synge, F.M., 1963. The glaciation of the Nephin Beg range. Ir. Geogr. 4, $386-397$.

Talbot, M.R., 2001. Nitrogen isotopes in palaeolimnology. In: Last, W.M., Smol, J.P. (Eds.), Tracking Environmental Change Using Lake Sediments, Vol. 2: Physical and Geochemical Methods. Kluwer Academic Publishers, Amsterdam, pp. 401439.

ter Braak, C.J.F., Šmilauer, P., 2002. CANOCO reference manual and CanoDraw for Windows. User's guide: software for canonical community ordination (version 4.5) Microcomputer Power, Ithace, New York, USA.

Watts, C., Naden, P.S., Cooper, D.M., Gannon, B., 2003. Application of a regional procedure to assess the risk to fish from high sediment concentrations. Sci. Total Environ. 314-316, 551-565., http://www.sciencedirect.com.libraryproxy.mic.ul.ie/science/article/pii/-COR1.

Weir, G., 1996. Sheep overgrazing in the Nephin Begs (MSc thesis). Trinity College, Dublin.

Whelan, K.F., Poole, W.R., McGinnity, P., Rogan, G., Cotter, D., 1998. The Burrishoole system. In: Moriarty, C. (Ed.), Studies of Irish Rivers and Lakes. Marine Institute, Dublin, p. p279.

Wolfe, B.B., Edwards, T.W.D., Beuning, K.R.M., Elgood, R.J., 2001. Carbon and oxygen isotope analysis of lake sediment cellulose: methods and applications. In: Last, W.M., Smol, J.P. (Eds.), Tracking Environmental Change Using Lake Sediments, Vol. 2. Physical and Geochemical Methods. Kluwer Academic Publishers, Amsterdam, pp. 373-400.

Wood, P.J., Armitage, P.D., 1997. Biological effects of fine sediment in the lotic environment. Environ. Manage. 21 (2) 203-217. 